\title{
Developing Mobile Learning Media for Arabic Language Instruction at Islamic Senior High School in Lampung Indonesia
}

\author{
Koderi, Achmad Maulana, Umi Hijriyah, Dwi Prasetyo, Rukimin
}

\begin{abstract}
This study aims to develop a mobile learning media for Arabic learning and to investigate the feasibility and effect of the developed media on students' learning outcome. This is a research and development study which involves a process to develop and validate educational product conducted at MAN 2 Bandar Lampung. This study employs the modified model of development proposed by Hannafin and Peck which consists of three phases: (1) needs analysis; (2) design; and (3) development/implementation. This research produces a product in the form of mobile learning media for Arabic learning at Islamic Senior High School (Madrasah Aliyah) with an offline operational system using a smartphone (Android). The product development process was done using Construct 2 software and Cocoon.io on the https://www.cocoon.io/. The product feasibility was validated by the material expert with the score of 4.85 or $97.14 \%$, by the media expert with the score of 5 of 100\%, and by the expert of instructional design with the score of 4.6 or $92 \%$. This means that all these three validations belong to the highly feasible category. The effectiveness of the product was tested using the t-test with a significant level of $\alpha=0.05$. Based on the result of calculations using the t-test, the obtained values of tcritical and ttablearetcritical $=14.342>$ ttable $=2.086$ with the differences in learning outcomes amounting 49.04462. It can be concluded that the mobile learning media of Arabic learning is very suitable to be used in learning and very effective to improve students' learning outcome. Compared to the previous studies, this current research comes up with relatively new ideas in terms of involving the four language skills in Arabic learning as well as the interactive quizzes for those skills. Not only does this make this product effective and efficient, but also comprehensive.
\end{abstract}

Index Terms: Arabic Language, Instruction, Mobile Learning, Media,

\section{INTRODUCTION}

The rapid development of information and technology has been able to influence the pattern of human activities in most

Revised Manuscript Received on September 22, 2019.

Koderi, Tarbiyah and Teacher Training Faculty, Raden Intan State Islamic University of Lampung, Indonesia , koderi@radenintan.ac.id

Achmad Maulana, Tarbiyah and Teacher Training Faculty, Raden Intan State Islamic University of Lampung, Indonesia am.maulanaibrahim@gmail.com

Umi Hijriyah, Tarbiyah and Teacher Training Faculty, Raden Intan State Islamic University of Lampung, Indonesia , umihijriyah@radenitan.ac.id

Dwi Prasetyo, Computer Science Departement, Faculty of Science and Engeneering, Nusa Cendana University of Kupang, Indonesia, dpras.ilkom.undana@gmail.com

Rukimin, Muhammadiyah University of Mataram, Indonesia, rukimin_rukimin@yahoo.com fields including economy, politics, social-culture, and also education. The current education process is required to develop and use information and technology for learning (The Regulation of the Ministry of Education no. 22 of 2016 concerning educational process standards). Therefore, learning media must be developed in accordance with the demands of the era. One of the many information technologies in the current era that is fancied by the public is the smartphone. The advantages possessed by the smartphone make people enthusiastic to welcome its presence to be used as a medium of communication and other activities, even as a part of a lifestyle. The use of the smartphone in Indonesia also increases every year according to the Emarketer, digital marketing research institutes (Rahmayani, 2015).

The use of the smartphone by teachers and students at schools as learning media is still limited. This is unsuitable with the original intended use of the smartphone which is a means of communication, such as telephone, SMS, chatting, Whatsapp, Youtube, and others. Hence, it is not strange for the smartphone to contain junk contents that do not have educational benefits for its owners.

A smartphone is designed as an innovative learning media, hereinafter referred to as mobile learning, can be accessed anytime and anywhere. It contains visual, audio, audio-visual, and interactive exercises. Pawar et al. claim that "with this mobile learning application, students could learn at their own speed and anytime".(Pawar, Ugale, Nigal, Shinde, \& Metkar, 2015)

Mobile learning is a learning model that utilizes smartphone as a learning device, both as a medium and as a tool, to guide the learning process. This mobile learning technology can be developed into an effective medium in learning Arabic. There are four language skills to be achieved (maharah al-lughah) in Arabic learning including listening skill (maharah al-istima'), speaking skill (maharah al-kalam), reading skill (maharah al-qira'ah), and writing skill (maharahal-kitabah). The Arabic learning process for non-native students aimed to achieve the four skills is always facing the following problems: 1) students' internal factors such as interest, talent, and motivation, 2) external factors such as teachers, curriculum, syllabus, teaching materials, learning models, strategy, and media and evaluation, and 3) linguistic factors such as sound, word form, sentence structure, and writing systems

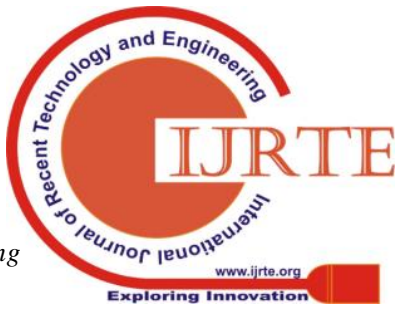


that are different from their mother tongue. (Koderi, 2018).

The researchers believe that if a smartphone can be developed into learning media, it will be able to increase students' motivation, retention, and Arabic language skills (maharah al-lughah). According to Heinich, there are four indicators of effective and efficient learning, namely 1) able to facilitate students to achieve the required abilities or competencies; 2) able to motivate students to explore the knowledge and skills learned; 3) able to make students remember the content or subject matter(retention); and 4) able to apply the knowledge learned in the right context (Koderi, 2014).

Based on the results of the preliminary research, the result of Arabic learning at MAN 2 Bandar Lampung was low as depicted in the following graph:

\section{Graph 1.}

The Result of the Eleventh Grade Students' Arabic Exam of the 2017/2018 Academic Year

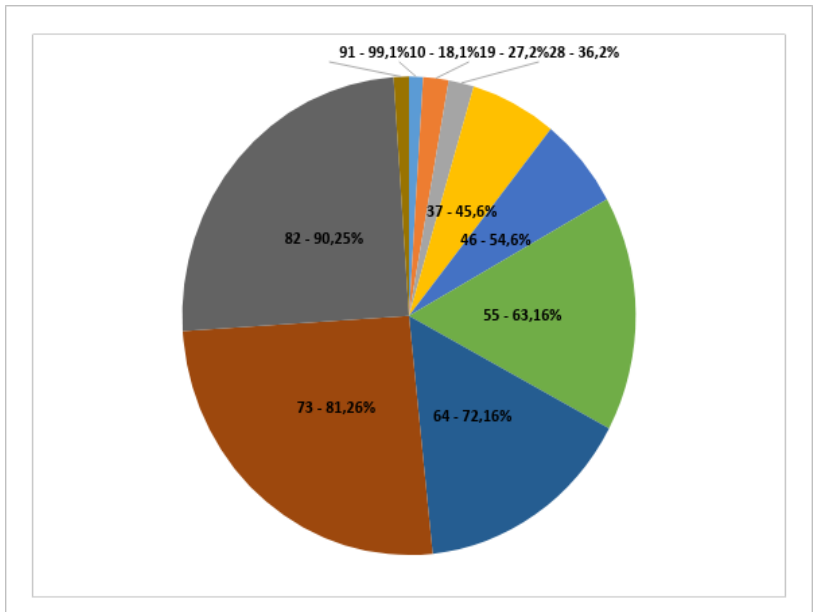

Based on the data,the achievement of Arabic learning of the students of the eleventh grade of MAN 2 Bandar Lampung was still low since those who scored 64-81 were only $41 \%$ of the total students.

Furthermore, based on the result of an interview with the Arabic teachers, it was known that the learning media used in the process of learning Arabic were blackboards, textbooks, internet facilities to translate Arabic words, and sometimes using LCDs.

To facilitate the students in order to improve their learning outcomes through the use of a smartphone, the researchers developed mobile learning media of Arabic learning for the students of Islamic Senior High School since mobile learning could make the students able to learn independently with an abundance of time.

This study is carried out to address the following questions: 1) How is it to develop effective Arabic mobile learning for Madrasah Aliyah students? And, 2) Can the Arabic mobile learning developed be effectively utilized to improve the learning outcomes of Arabic learning? Hence, the objectives and significances of this study are: 1) to contribute to the development of Arabic mobile learning media to facilitate learning, 2) to provide media and learning resources for students in accordance with the accessibility of the technological developments, 3) to provide learning media that is relevant to the advancement of information and technology that can help teachers to conduct Arabic learning effectively and efficiently.

\section{LITERATURE REVIEW}

According to Smaldino et al., media is the plural form of the word medium which means communication. It is derived from the Latin word medium (Between). The term refers to anything that carries information between a source and a receiver (Smaldino, S. E., Lowther, D. L., \& Russell, 2008). Learning is a process of setting information and environment to facilitate the students to interact with the teachers and other sources of learning to achieve goals which are carried out directly by using the media. Therefore, learning requires learning media or instructional media as communication tools to make the learning process more effective (Yetri, Koderi, Amirudin, S Latifah, 2019). Learning media can also be defined as all tools capable of carrying messages or instructional information. Learning media is a technology designed to convey messages used for learning activities. The message or teaching material delivered is all the learning materials that have been formulated as the competency objectives. Learning media consists of two elements, namely equipment (hardware) and the message (message/software). Tools (hardware) are all tools that can be used to convey messages (message/software). Message/software is all instructional information that will be delivered to students. It can be in the form of visual text, images, audio, and audio-visual.

The use of media in learning must consider learning objectives, subject characteristics, the ability of the teachers, and the differences of students' characteristics, including their attitude toward technology, independence, and conditions. Through the use of learning media, learning activities can take place in various learning strategies, namely: 1) media-based learning; the teachers and learning designers must be able to develop the media needed, 2) learning media; the teachers simply use the available media, 3) the teachers share roles with the media; the teachers manage the environment and learning resources in order to be a medium for presenting messages, 4) learning with only the media that allows for independent learning.

Arabic learning material that is in the form of abstract symbols can be delivered concretely using learning media so that it can be easier for students to select information, understand, store and, recall information. Various events, concepts, or learning procedures can be addressed in the media through text, images/illustrations, and recordings in visual, audio, and audio-visual to provide experience directly to the students.

Furthermore, Arabic learning in the era of industrial revolution 4.0 is marked by the emergence of modern telecommunications media, namely smartphones and android that have changed people's lives. Teachers in this industrial revolution era must be able to improve self-understanding in designing the learning, expressing themselves in the development of learning 
media literacy, understanding the characteristics of information that will be taught to the students, and carrying out research development to solve educational problems through digital media literacy. The hope is that it can be able to change the performance of education of Arabic learning based on applications. The learning model that uses application-based digitalization media is the mobile learning model.

Mobile learning media literally consists of the word mobile which means moving and learning which means acquiring knowledge. The term mobile learning in educational technology means that it can move without being bound by place and time. Mobile learning is a learning model that utilizes a smartphone for learning, both as a medium (message channel) and as a tool to guide the learning process. Keegan cited by Korucu and Alkan explains that mobile learning as running of education through PDAs, pocket PCs, and mobile phones"(Korucu \& Alkan, 2011). John Traxler says: "This means that mobile learning can include mobile phones, smart phones, personal digital assistants (PDAs) and their peripherals, perhaps tablet PCs and perhaps laptop PCs"(Traxler, 2015).

Based on the characteristics of learning using the mobile learning model, students can access the learning materials in any place and at any time so that they can learn independently. Lehner et al. cited by Siraj explain that there are two strengths as the characteristic of the mobile learning model namely anytime, anywhere learning and teaching while doing(Saedah Siraj, 2004). This shows that if it is designed according to the needs and characteristics of students, mobile learning will provide more time and more learning opportunities. In addition, the selection of material in learning will also be flexible according to the wishes of students and they can do exercises wherever and whenever, as long as there is time and opportunity so that it will increase their interest and motivation in learning and improve learning outcomes.

Majid quoted by Azmi explains that there are three functions of mobile learning in the learning process, namely as an addition (supplement) that is optional in nature, complement, and substitute(Azmi, 2015). Mobile learning can function as a supplement if students have the freedom to use it or not. Mobile learning can function as a compliment if it is used as a complementary learning material taught to students in the class. In this case, mobile learning acts as a reinforcement or remedial for students who cannot meet the standards. Mobile learning that functions as a substitution if the learning activity model fully uses mobile learning. It allows students to use their time flexibly in managing their learning programs according to their available time and activities.

Majid explains that the benefits of mobile learning for students, among others: 1) mobile learning can facilitate learning in small schools of poor areas to acquire certain lessons that cannot be given at the schools, 2) mobile learning provides benefits to the home-schooling students, 3) mobile learning could also be utilized by students who have school phobia, students who are undergoing treatment at the hospital or at home, students who drop out of schools but are interested in continuing their education, students who live in various regions and even abroad, 4) and students who are not accommodated in conventional schools to continue their education.

The benefits of mobile learning for teachers include: 1) easier to do instructional materials innovations, 2) develop or do research to add insight, 3) control the activities of students. It even enables the teachers to find out the topic being studied, when students learn, how long a topic is studied, and how many times a particular topic is re-learned, 4) check whether students have worked on practice questions after studying a particular topic, 5) correct the answers and notify the students (Sharples, Spikol, \& Majid, 2012).

Furthermore, the benefits of using mobile learning in general according to Elias and Lee cited by Mehdipour and Zerehkafi are: 1) more affordable than buying PCs and laptops, 2) more diverse and varied in delivering the learning material, 3) encouraging the teachers to carry out continuous learning because students always have their smartphones on them, 4) lowering the cost of the learning process because it does not have to be conducted in class, 5) having a better potential in providing experiential learning, 6) increasing literacy, 7) increasing the number of participants in education, and 8) having more communication features because they are able to send text, audio, and audio-visuals between mobile phones (Mehdipour, 2013).

According to Tamimuddin, the contents of mobile learning consist of several types, including 1) text, one example of text utilization is SMS (Short Message Service). The relatively small memory needed by the text-based content is easier to implement. However, the limited number of characters that can be displayed must be taken into consideration in displaying learning content so that a special strategy is needed for the learning content to be delivered accurately and effectively despite these limitations, 2) images, almost all available devices support the image feature. The types of images supported by the devices are PNG, GIF, and JPG. The use of the image can be combined with the use of text, 3) audio, all devices support the audio. The types of audio files commonly used are rm, mp3, amr, and many others, 4) videos, many devices can now use video even in limited quantities. The common file types of videos are 3gp, MPEG, MP4, etc., 5) software applications, the software can combine the above content such as text, images, audio, and video so that the device becomes more interactive (Tamimuddin, 2007).

According to Lynda, mobile learning provides many advantages, namely: 1) learning can be done online or offline so that the students can keep learning even though the Wi-Fi or internet connection is slow, 2) Learning is more optimal in achieving the results and experience of expected learning since the learning is also more focused by using small personal microphones, 3) Learning will be more convenient because the cellular device can be used within a short period of time, easy to adjust with the condition and situation, for example; traveling, meeting, and within

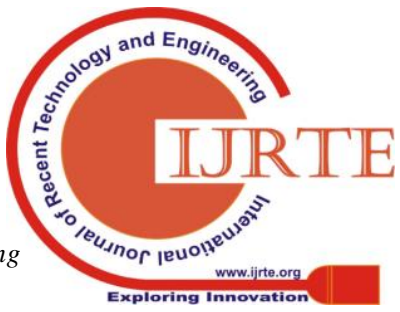


day time and night time, 4) Learning will always continue because the students are taught to be able to synchronize activities with all devices, and 5) students can begin learning in one type of device then use different types of devices to continue learning where they left off, for example: the students can access learning on the mobile device and then continue the learning on a laptop, tablet, or PC (Lynda.com, 2015).

Therefore, the use of mobile learning puts forth the following advantages: 1) it can be used anywhere and anytime, 2) most mobile devices are relatively cheaper than the price of a desktop PC, 3) the size of the device is small and light compared to Desktop PCs, 4) it is expected to involve more learners because mobile learning utilizes technology commonly used in everyday life.

Indeed mobile learning possesses several advantages but it also has several disadvantages, including 1) processor capability, 2) memory capacity, 3) display screen, 4) battery capacity and5) I/O devices. The weaknesses in this mobile learning will be overcome by the increasingly sophisticated technological developments. Today's technological sophistication can be used to develop everything in order to run effectively and efficiently. Especially in education, through mobile learning, it is hoped that it can be used wisely to improve the quality of learning.

\section{METHODOLOGY/MATERIALS}

This is a Research and Development study. According to Borg and Gall (1989) in (Sugiyono, 2017) Educational Research and development (R \& D) is a process used to develop and validate educational products research was conducted at MAN 2 Bandar Lampung. The approach of the method is the one proposed by Hannafin and Peck model which consists of three phases with modifications. The first phase is needs analysis, the second phase is design, and the third phase is development and implementation. Each phase is connected by evaluation and revision activities.

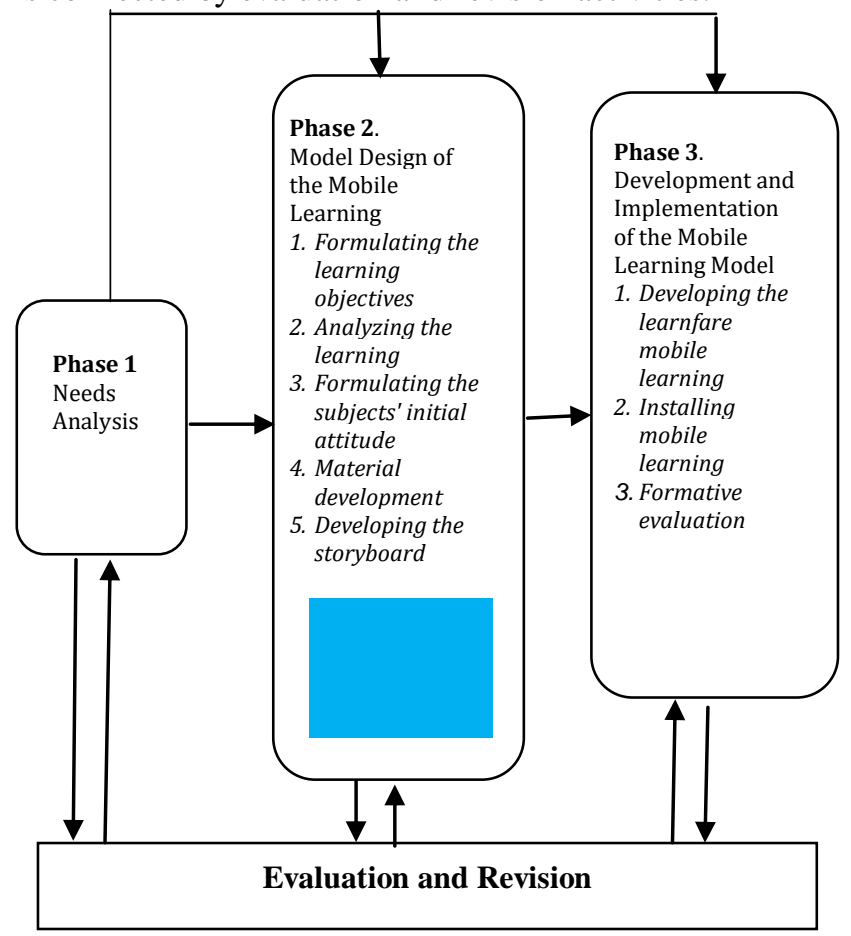

Fig 1.The Syntax of the Modified Mobile Learning Development Model by Hannafin \& Peck's
The first phase in this study was a needs analysis carried out at the beginning of the development to identify whether mobile learning was needed in an effort to overcome the low motivation and Arabic learning outcomes. In this phase, the researchers conducted an interview with the Arabic teachers, observed the learning support facilities, and analyzed the results of the Arabic final test. Based on the results of the interview and observation, the researchers obtained the following data: 1) Arabic learning in MAN 2 Bandar Lampung was done using the 2013 curriculum, 2) Almost all students had smartphones with the Android operating system, 3) Media used in learning Arabic were blackboards, textbooks, and internet facilities to translate Arabic words.

The second phase was the design. After getting the data needed in the first phase, the data was formatted into an Android-based mobile learning media by 1) formulating the learning objectives, 2) formulating the skills of prospective users, 3) compiling material, 4) making storyboards.

The third phase was the development and implementation. In the initial stage, the developer created an Android application and installed the application as an initial product that will be validated by experts, namely material experts, media experts, and learning design experts. Validation was done to see the feasibility of the product through criticism/suggestions/input to improve or revise the developed mobile learning media for Arabic learning.

In the implementation phase, the researchers tested the product to find out its effectiveness for learning Arabic. Product trials consisted of an individual trial (one to one learner), small-group trial, and large-group trial (field-trial).

\section{RESULTS AND FINDINGS}

This research produces a product in the form of mobile learning media for Arabic learning at Islamic Senior High School (Madrasah Aliyah) with an offline operational system using a smartphone (Android). The product development process was done using Construct 2 software and Cocoon.io on the https://www.cocoon.io/. Construct 2 was used to make the product's learnware program (draft 2) and the cocoon.io was used to export the learnware file program into apk extension file (final draft) which is an extension to the mobile learning application on smartphones (Android/OS).

The validation by learning material expert, media expert, and instructional design expert is utilized to determine the feasibility of the developed product. The result of the material expert validation was 4.85 or $97.14 \%$, the result of validation by media expert was 5 or $100 \%$, the validation by the instructional design expert was 4.6 or $92 \%$. Based on the results of the experts' validation, the developed mobile learning is highly feasible to be used in Arabic learning.

Furthermore, the individual trial (one to one learner), small group trial, and field trial were conducted to obtain the students' responses on the usefulness of the developed mobile learning media. 
The results of the individual trial (one to one learner) obtained an average score of 2.71 or $90 \%$, the result of the small-group trial was 7.10 or $88 \%$, and the result of the large-group trial (field trial) was 19.17 or $91 \%$. Based on the results of the trials, it can be concluded that the developed mobile learning media was feasible and can be used for Arabic learning process.

Product implementation was carried out to determine the effectiveness of the developed product towards students' learning outcomes in Arabic. Researchers used pre-test and post-test as the data collection techniques in the form of multiple-choice questions. Paired sample t-test was used to calculate the score of pre-test and post-test. Before the t-test analysis was conducted, the normality test and homogeneity test were carried out as a prerequisite for conducting the t-test analysis.

The normality test is a prerequisite test to find out whether the data used in the study is normally distributed or not so that it can be used to test the hypothesis. The normality testing technique of this study was the Liliefors test. The homogeneity test used in this study was the F-test. The results of the normality and homogeneity tests calculation showed that the data of pre-test and post-test was normally distributed and homogeneous.

Based on the results of calculations using the t-test, it was obtained that the value of $t_{\text {critical }}=14.342$ while the value of $t_{\text {table }}=2.086$ at a significant level of $\alpha=0.05$. The result of the comparison between the values of $t_{\text {critical }}$ and $t_{\text {table }}$ was $\mathrm{t}_{\text {critical }}=14.342>\mathrm{t}_{\text {table }}=2.086$. Then, $\mathrm{H}_{0}$ from the hypothesis was rejected and $\mathrm{H}_{1}$ was accepted. Furthermore, it could be concluded that the developed mobile learning media of Arabic learning for the students of MAN 2 Bandar Lampung is effective in improving students' learning outcomes.

The research on the mobile learning media development of Arabic learning for Islamic Senior High School (Madrasah Aliyah) is supported by previously conducted studies. The aspect that makes this research different from the previous studies lies in the object of the research.

The first research on mobile learning media is entitled Developing an Android-based Chemical Learning Media to Improve Learning Motivation and Cognitive Achievement of High School Students. The results of the research are: (1) Android-based chemical learning media have such characteristics as interesting, practical, flexible visualization, and varied evaluation questions, (2) Android-based chemical learning media is feasible to be used in learning in terms of material aspects, media aspects, and the results of student trials, and (3) there is a significant increase on the students' learning motivation and cognitive achievement compared to conventional learning (Lubis \& Ikhsan, 2015).

The second study entitled Development of Adaptive Mobile Learning in High School Biology Subjects as an Effort to Support the blended learning process. The results of the study are: (1) the Adaptive Mobile Learning is declared feasible as learning media based on the validation of material experts, media experts, and users with feasibility averages scores reaching 3.35 which belongs to the excellent category; (2) the usefulness of the product is proven through differences in learning outcomes that reaches 33.80after using Adaptive Mobile Learning and proven to support blended learning with a score of 3.42 which belongs to the excellent category. It can be concluded that the Android-based learning media developed by the researchers is feasible and effective to be used in biology learning (Surahman \& Surjono, 2017).

The third study entitled Development of Mobile Learning Media by Using Android Applications in Electrical Engineering Subjects at Jetis 1 State Vocational School of Mojokerto shows that the level of the feasibility of the developed learning media is excellent with the percentage of $83 \%$. Judging from the effectiveness of the product on student learning outcomes, it is obtained that $\mathrm{t}_{\text {critical }}=$ $10.281>t_{\text {table }}=2.001$. It can be concluded that there is a very significant difference in students' learning outcomes between the experimental class and the control class. Based on the results of the research, it can be concluded that the Android-based learning media developed by the researchers is feasible and effective to be used in learning electrical engineering (Handayani, 2017).

The fourth study entitled Utilization of Mobile Learning Games of Geometry Sequences and Series to Increase the Interest on Mathematics Subject and Learning Outcomes of Kesatrian 1 Senior High School Semarang with the percentage of students' interest in learning mathematics that reaches $20.57 \%$ and the percentage of students' mathematics learning outcomes that reach $10.86 \%$. The results of the study concluded that the Android-based learning media developed by the researchers were feasible and effective to be used in mathematics learning (Nugroho, 2014).

\section{CONCLUSION}

The development process of mobile learning media of Arabic learning at the Islamic Senior High School (Madrasah Aliyah) was done using Construct 2 software and using the Hannafin and Peck development model. Hannafin and Peck's model is a three-phase learning media development model. The phases are needs analysis, design, and development and implementation.

The developed mobile learning media of Arabic learning at the Islamic Senior High School (Madrasah Aliyah) was useful. This is indicated by the results of the material expert validation (4.85 or $97.14 \%$ ), media expert validation (5 or $100 \%)$, and instructional design expert (4.6 or $92 \%)$. The developed mobile learning media of Arabic learning for Islamic Senior High School is proven effective in improving students' learning outcome in Arabic learning. This is evidenced by the result of statistical analysis using the t-test. Based on the results of the t-test analysis by comparing the values of tcritical and ttables at a significant level of $\alpha=$ 0.05 , it can be seen that the value of tcritical is greater than ttable with the value of $4.178>2.086$. The average score of the pre-test (initial test) was 40.452381 and the average score of the post-test (final test) was 90 with the students' 
progress value of 49.04462 . This means that the mobile learning media of Arabic learning for students of Islamic Senior High School (Madrasah Aliyah) is effective in improving learning outcomes.

Compared to the previous studies, this current research comes up with relatively new ideas in terms of involving the four language skills in Arabic learning as well as the interactive quizzes for those skills. Not only does this make this product effective and efficient, but also comprehensive.

\section{REFERENCES}

[1] Azmi, M. (2015). Pengembangan Mobile Learning Sebagai Alternatif Media Pembelajaran Di Masa Depan. Jurnal Teknodika, 1-13.

[2] Ence Surahman, \& Herman Dwi Surjono. (2017). Pengembangan adaptive mobile learning pada mata pelajaran biologi SMA sebagai upaya mendukung proses blended learning. Jurnal Inovasi Teknologi Pendidikan, 4(1). https://doi.org/10.21831/jitp.v4i1.9723

[3] Handayani, A. (2017). Pengembangan Media Pembelajaran Mobile Learning Dengan Menggunakan Aplikasi Android Pada Mata Pelajaran Teknik Listrik Di Smk Negeri 1 Jetis Mojokerto. Pendidikan Teknik Elektro, 6(2), 205-212.

[4] Koderi. (2014). Pembelajaran Bahasa Arab Berbasis Media iPAD. Al-Bayan, 6(2), 1-18.

[5] Koderi. (2018). Penerapan Model Pembelajaran Bahasa Arab Berbasis SAVI ( Somatis, Auditori, Visual, Intelektual ) Dalam Meningkatkan Hasil Belajar, 10(1), 75-85. https://doi.org/DOI: https://doi.org/10.24042/albayan.v10i01.2596

[6] Korucu, A. T., \& Alkan, A. (2011). Differences between m-learning (mobile learning) and e-learning, basic terminology and usage of m-learning in education. Procedia - Social and Behavioral Sciences, 15, 1925-1930. https://doi.org/10.1016/j.sbspro.2011.04.029

[7] Lubis, I. R., \& Ikhsan, J. (2015). Pengembangan Media Pembelajaran Kimia Berbasis Android Untuk Meningkatkan Motivasi Belajar Dan Prestasi Kognitif Peserta Didik Sma. Jurnal Inovasi Pendidikan IPA, I(2), 191. https://doi.org/10.21831/jipi.v1i2.7504

[8] Lynda.com. (2015). Benefits of Mobile Learning, 1 (Mobile Learning), 9. https://doi.org/10.1057/9781137309815_1

[9] Nugroho, S. (2014). Pemanfaatan Mobile Learning Game Barisan Dan Deret Geometri Untuk Meningkatkan Minat Dan Hasil Belajar Matematika SMA Kesatrian 1 Semarang. Jurnal Indonesian Digital Journal of Mathematics and Education, Vol. 1, 1-7.

[10] Pawar, P. U. B., Ugale, C. B., Nigal, A. S., Shinde, R., \& Metkar, M. (2015). Mobile Learning Application with Online Query Support. IJMTER (International Journal of Modern Trends in Engineering and Research), 2(10), 239-244.

[11] Rahmayani, I. (2015). Indonesia Raksasa Teknologi Digital Asia.

[12] Saedah Siraj. (2004). Pembelajaran Mobile dalam kurikulum masa depan. Jurnal Pendidikan, Journal on Isues of Education, 27(July), 129-141.

[13] Sharples, M., Spikol, D., \& Majid, A. (2012). Mobile Learning. Technology Enhanced Learning, 89-96. https://doi.org/10.1007/978-3-319-02600-8_8

[14] Smaldino, S. E., Lowther, D. L., \& Russell, J. D. (2008). Instructional Technology and Media for Learning. New York, USA: Prince Hall.

[15] Sugiyono. (2017). Metode Penelitian: Kualitatif, Kuantitatif, dan R\&D. Bandung: Alfabeta.

[16] Tamimuddin. (2007). Mengenal Mobile Learning (M-Learning). LIMAS, 1-8.

[17] Traxler, J. (2015). Defining Mobile Learning. IADIS International Conference Mobile Learning, (November), 261-266.

[18] Yetri, Koderi, Amirudin, S Latifah, M. D. A. (2019). The Effectiveness of Physics Demonstration Kit: The Effect on The Science Process Skills Through Students ' Critical Thinking The Effectiveness of Physics Demonstration Kit: The Effect on The Science Process Skills Through Students ' Critical Thinking. IOP Conf. Series: Journal of Physics: Conf., 1155(012061), https://doi.org/10.1088/1742-6596/1155/1/012061

[19] Yousef Mehdipour, \& 2, H. Z. (2013). Mobile Learning for Education: Benefits and Challenges. International Journal of Computational Engineering Research, 3(6), 93-101. https://doi.org/10.1080/87567555.2011.604802

\section{AUTHORS PROFILE.}

Koderi affiliated with Tarbiyah and Teacher Training Faculty, Raden Intan State Islamic University of Lampung, Indonesia. My area of interest is e learning, research and development.

Achmad Maulana from Tarbiyah and Teacher Training Faculty, Raden Intan State Islamic University of Lampung, Indonesia. My area of interest is e learning, research and development.

I am Umi Hijriyah, Tarbiyah and Teacher Training Faculty, Raden Intan State Islamic University of Lampung, Indonesia, My area of interest is e learning, research and development.

Dwi Prasetyo from Computer Science Departement, Faculty of Science and Engeneering, Nusa Cendana University of Kupang, Indonesia, dpras.ilkom. my area of interest is research and development.

Rukimin, Muhammadiyah University of Mataram, Indonesia. My area of interest is social science. 